Gulawentah: Jurnal Studi Sosial

ISSN 2528-6293 (Print); ISSN 2528-6871 (Online)

Vol. 5, No. 1, Juni 2020, Hal 40-51

Tersedia online: http://e-journal.unipma.ac.id/index.php/gulawentah

\title{
Peningkatan Sopan-Santun dan Disiplin melalui Tembang Dolanan pada Siswa TKIT AI Furqon Maospati Magetan
}

\author{
Siti Samsiyah*, Muhammad Hanif, dan P Parji \\ Program Studi Magister Pendidikan Ilmu Pengetahuan Sosial, Program Pascasarjana, \\ Universitas PGRI Madiun, Jl. AURI No.16 Kota madiun, Indonesia \\ Email: *ssamsiyah37@gmail.com; hanif@unipma.ac.id; parji@unipma.ac.id
}

Naskah diterima: 10/5/2020; Revisi: 21/5/2020; Disetujui: 31/5/2020

\begin{abstract}
Abstrak
Siswa TKIT Al Furqon Maospati Magetan pada umumnya belum mengenal dan bersikap sopan santun dan belum disiplin. Salah satu sebabnya gurunya kesulitan sarana untuk menginternalisasikan sopan santun dan disiplin. Padahal sopan-santun dan kedisiplinan merupakan bagian dari karakter yang harus dibangun sejak usia dini. Untuk itu perlu dilaksanakan penelitian ini dengan tujuan untuk meningkatan sopan santun dan disiplin siswa TKIT Al Furqon dengan tembang dolanan. Metode penelitiannya menggunakan tindakan kelas sebanyak dua siklus. Waktu pelaksanaan bulan Oktober 2019 sampai Januari 2020. Pengambilan datanya dengan observasi dan pencatatan dokumen. Data yang diperoleh dianalisis analisis kuantitatif dan kualitatif. Hasil penelitian menunjukkan bahwa sopan santun dan disiplin siswa TKIT Al Furqon dapat ditingkatkan melalui tembang dolanan. Pada siklus I sopan santun adalah $30 \%$ dan pada siklus II meningkat menjadi $87,25 \%$. Sedangkan disiplin pada siklus I sebesar 36,25\% dan pada siklus ke-2 menjadi $86,25 \%$. Dengan demikian capaian ketuntasan sudah tercapai karena sudah melebihi indikator kinerja yang ditetapkan sebesar $80 \%$.
\end{abstract}

Kata kunci: sopan santun; disiplin; tembang dolanan

\section{Improvement of Polite and Discipline through Dolanan Song for TKIT Al Furqon Maospati Magetan Students}

\begin{abstract}
TKIT Al Furqon Maospati Magetan students in general do not know and behave politely and are not disciplined. One reason is the difficulty of the teacher's means to internalize courtesy and discipline. Though manners and discipline are part of the character that must be built from an early age. For this reason, this research needs to be carried out with the aim of increasing the courtesy and discipline of TKIT Al Furqon students with dolanan songs. The research method uses two cycles of class action. The implementation time is from October 2019 to January 2020. Data is collected by observation and document recording. The data obtained were analyzed quantitative and qualitative analysis. The results showed that the manners and discipline of TKIT Al Furqon students could be improved through dolanan song. In the first cycle the manners were $30 \%$ and in the second cycle increased to $87.25 \%$. While the discipline in the first cycle was $36.25 \%$ and in the second cycle it became $86.25 \%$. Thus the achievement of completeness has been achieved because it has exceeded the specified performance indicators by $80 \%$.
\end{abstract}

Keywords: manners; discipline;dolanan song

DOI: $10.25273 /$ gulawentah.v5i1.6631

Some rights reserved. 


\section{Pendahuluan}

Sopan santun dan disiplin merupakan bagian dari karakter dan penting bagi generasi penerus. Sehingga generasi penerus tidak cukup hanya diberi bekal aspek kognitif saja tetapi perlu juga aspek psikomotor dan afektif (moral dan spiritual). Hal ini sebagaimana digariskan dalam Undang-Undang Republik Indonesia Nomor 20 Tahun 2003 Tentang Sistem Pendidikan Nasional yang menyatakan bahwa pendidikan nasional berfungsi untuk membangun karakter. Oleh karena itu pendidikan karakter harus dibangun sejak usia dini. Pendidikan karakter di prasekolah dimulai dengan memberikan contoh atau teladan dan diiringi pemberian pembelajaran seperti keagamaan dan kewarganegaraan sehingga dapat membentuk individu yang berjiwa sosial, berpikir kritis, memiliki dan mengembangkan cita-cita luhur, mencintai dan menghormati orang lain, serta adil dalam segala hal. Mengingat karakter ini berkaitan dengan moral dan sekarang berada dalam era informasi maka strategi pembelajarannya perlu menggunakan pengetahuan secara bermakna, memanusiakan siswa, kontekstual, dan penekanan pada proses (Parji Parji, 2002). Strategi ini akan dapat menghasilkan siswa yang tidak hanya memiliki kompetensi kognitif saja tetapi juga afektif (akhlak). Hal ini penting karena berbekal akhlak mulia ini siswa akan berkembang menjadi dewasa, berkarakter yang kuat, bermanfaat bagi nusa dan bangsa.

Dalam pendidikan anak usia dini dilakukan dengan tujuan memberikan konsep yang bermakna bagi anak, dalam kesempatan ini, pembentukan karakter dibangun secara ikonik, simbolik, dan hal yang konkrit sehingga siswa mudah menangkapnya. Sehingga guru PAUD dan TK bukan hanya sekedar menjadi pengingat akan tetapi juga sebagai contoh. Namun hal itu belum dilakukan dengan nyata oleh guru-guru TKIT Al Furqon Maospati Magetan sehingga siswanya pada umumnya belum mengenal sopan-santun dan tidak disiplin. Oleh karena itu perlu adanya solusi alternatif, satu diantaranya dengan media tembang dolanan (nyanyian sebagai pengiring anak-anak bermain). Hal tersebut karena tembang dolanan merupakan bentuk kesenian dan kesenian memiliki bobot besar dalam kebudayaan, kesenian sarat dengan kandungan nilai-nilai budaya, bahkan menjadi wujud dan ekspresi yang menonjol dari nilai-nilai budaya (Hanif, 2016). Menurut Khodiri (2019) juga menyampaikan bahwa tembang dolanan merupakan suatu hal yang menarik dan mengandung ajaran-ajaran atau nilai-nilai budi pekerti dan sesuai dengan perkembangan jiwa anak yang masih suka bermain.

Tembang dolanan merupakan sejenis lelagon (nyanyian). Lelagon itu memiliki aturan yang bebas (manasuka). Manasuka berarti bebas, meskipun tidak bebas sama sekali. Bebas, berarti aturan yang mengikat tidak terlalu ada (Suwardi, 2009). Menurut pendapat ahli tersebut dapat dikatakan bahwa lagu dolanan adalah jenis lagu Jawa yang bebas tanpa ada aturan yang mengikatnya sehingga lagu dolanan dapat dilagukan dengan berbagai bentuk versi. Berbagai bentuk versi tersebut yang mengakibatkan pembelajar mudah untuk mempelajari tembang dolanan tersebut. Lebih lanjut Kusnadi (1999) menyatakan bahwa tembang dolanan biasanya dipergunakan dalam bermain anak-anak.

Tembang dolanan selain sebagai pengiring anak-anak untuk bermain dan bersenangsenang, tembang dolanan berfungsi juga sebagai media komunikasi yang mengandung nilai-nilai edukatif. (Khodiri, 2019). Jatirahayu dan Pringgawidagda (2002) juga menegaskan bahwa "Para winasis angggone paring pitutur ora cablaka (langsung), nanging disamarake kanthi cara kang laras karo sing diwenehi pitutur. Kaya dene lagu dolanan. Ancase kajaba gawe seneng gumbiraning bocah, uga kanthi alon-alon nanging temanja pitutur becik rumasuk ing dhiri pribadine bocah (internalisasi). Pitutur becik iku lumrahe diarani budi pekerti". Maksud dari pernyataan tersebut adalah para orang tua ketika memberikan suatu nasihat tidak dibicarakan secara langsung, tetapi disamarkan dengan lagu (laras) serta diberikan nasihat didalamnya, seperti tembang dolanan. Tujuannya selain membuat senang anak-anak secara perlahan-lahan nasihat itu akan diserap dan dilaksanakan. Nasihat yang baik itu dinamakan budi pekerti dan/atau karakter. Adapun karakter yang diteliti dalam penelitian ini yaitu sopan santun dan kedisiplinan. 
Sopan santun merupakan sikap yang patuh, hormat dan beradab, santun (halus dan baik hati) dalam tutur kata, budi bahasa, dalam bertindak dan berperilaku yang baik sesuai dengan adat istiadat dan budaya setempat (Mustari, 2014). Lebih jelas Zuriah (2007) menyampaikan sopan santun sebagai norma tidak tertulis yang mengatur bagaimana seharusnya bersikap dan berperilaku. Sebagai istilah dalam istilah bahasa jawa, sopan santun dapat diartikan sebagai perilaku seseorang yang menjunjung tinggi nilai-nilai. Dengan kata lain, sopan santun adalah suatu tata cara atau aturan yang turun-temurun dan berkembang dalam suatu budaya masyarakat, yang bermanfaat dalam pergaulan dengan orang lain, agar terjalin hubungan yang akrab, saling pengertian, hormat menghormati menurut adat yang telah ditentukan.

Axia dan Baroni (dalam Dessler, 2003) menyatakan bahwa politeness is a complex linguistic means used to maintain good interactions with other people yang artinya kesopanan adalah kebahasaan yang kompleks -meliputi bahasa verbal, intonasi bicara, gestur tubuh, dan mimik wajah-yang bermakna dan digunakan untuk memelihara interaksi yang baik dengan orang lain. Chazawi (2007) juga menandaskan bahwa sopan santun berisi nilai-nilai positif yang dicerminkan dalam perilaku positif. Perilaku positif lebih dikenal dengan santun diimplementasikan pada cara berbicara, cara berpakaian, cara memperlakukan orang lain, cara mengekspresikan diri dimanapun dan kapanpun. Peran dari kesopanan adalah untuk memelihara suatu hubungan yang harmonis antar pribadi sepanjang interaksi tersebut yang dibingkai dalam sebuah aturan/tata tertib tertentu.

Kepatuhan seseorang dalam mengikuti peraturan atau tata tertib karena didorong oleh adanya kesadaran yang ada pada kata hatinya tanpa adanya paksaan dari pihak luar disebut disiplin. Lebih jauh Bejo (2005) memberikan pengertian disiplin sebagai suatu sikap menghormati, menghargai, patuh, dan taat terhadap peraturan-peraturan yang berlaku, baik yang tertulis maupun tidak tertulis serta sanggup menjalankannya dan tidak mengelak untuk menerima sanksi-sanksinya apabila ia melanggar tugas dan wewenang yang diberikan kepadanya. Prasojo (dalam Wulandari, 2017) menegaskan bahwa kedisiplinan merupakan faktor yang berasal dari dalam diri siswa yang dapat mempengaruhi pencapaian hasil belajar siswa di sekolah. Siswa yang memiliki disiplin tinggi, ia akan bersedia memenuhi peraturan yang diberikan padanya dan larangan-larangan tanpa adanya paksaan, sehingga disiplin menjadi kesadaran dalam diri siswa. Disiplin ini menurut Hadianti (2008) dapat membantu kegiatan belajar, dapat menimbulkan rasa senang untuk belajar dan meningkatkan hubungan sosial.

Dengan demikian aspek sopan santun dan disiplin merupakan bagian integral dari karakter. Sopan santun memiliki aturan dan nilai-nilai yang hanya bisa dipatuhi dengan adanya sikap displin. Dengan demikian, jika anak senang tembang dolanan yang didalamnya disisipkan pesanpesan tentang sopan santun dan kedisiplinan, maka karakter siswa TKIT Al Furqon dapat terbentuk dan/atau ditingkatkan.

\section{Metode Penelitian}

Penelitian ini dilaksanakan di TKIT Al Furqon Kecamatan Maospati Kabupaten Magetan. Adapun yang menjadi subyek penelitiannya yaitu siswa B3 yang berjumlah 20 anak, terdiri dari 12 anak laki-laki dan 8 anak perempuan dan seorang guru . Guru tersebut bertindak sebagai praktikan dan berkolaborasi dengan peneliti sebagai pengamat. Penelitian dilakukan dengan model Penelitian Tindakan Kelas (PTK) sebanyak 2 siklus. Adapun prosedurnya sebagaimana gambar 1. 


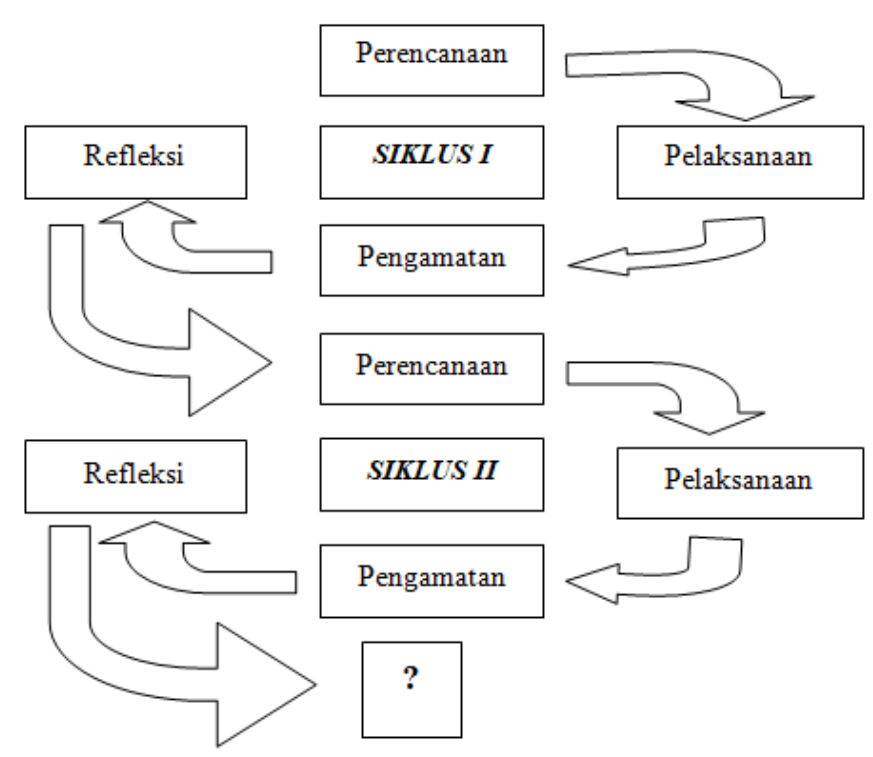

Gambar 1. Metode Pelaksanaan PTK

(Sanjaya, 2009)

Adapun indikator kinerjanya meliputi ketuntasan sikap sopan-santun dan kedisiplinan siswa mencapai minimal atau sama dengan $80 \%$ dari total siswa. Indikator sopan santun yang digunakan adalah kebiasaan verbal dalam mengucapkan kata "terima kasih" saat diberi sesuatu, mengucap kata "tolong" saat meminta bantuan, dan mengucap "maaf" bila melakukan kesalahan, dan mengucap salam dan mencium tangan guru. . Indikator disiplin yang digunakan adalah Dari aspek-aspek di atas yang dapat diamati kemunculannya dalam proses pembelajaran adalah membereskan mainan dan alat tulis usai kegiatan, mengikuti kegiatan pembelajaran sampai tuntas, dan perilaku tertib saat dalam antrian.

Waktu penelitian mulai bulan Oktober 2019 sampai dengan bulan Januari 2020. Sedangkan pengambilan datanya dengan observasi. Observasi ini menjadi instrumen utama dalam penelitian ini dan dilakukan oleh peneliti. Selain itu, data dikumpulkan dengan cara wawancara dan mencatat dokumen. Hal ini sejalan dengan pendapat Sanjaya (2009) bahwa analisis kualitatif digunakan untuk menentukan peningkatan proses belajar khususnya tindakan yang dilakukan guru dengan tembang dolanan. Sedangkan analisis kuantitatif digunakan untuk menentukan peningkatan hasil belajar (sopan-santun dan kedisiplinan) siswa sebagai pengaruh dari tindakan guru dengan tembang dolanan.

\section{Hasil dan Pembahasan}

\section{Hasil}

\subsection{Pra Siklus}

Hasil observasi awal terhadap guru kelas B3 TKIT Al Furqon dalam melaksanakan pembelajaran lebih banyak verbalistis tanpa ikonik dan simbolik. Adapun sopan santun (mengucapkan terimakasih jika diberi sesuatu, mengucapkan minta tolong jika perlu bantuan, minta maaf jika salah, dan mengucapkan salam dan mencium tangan guru) dan disiplin (merapikan mainan dan alat tulis, mengikuti kegiatan dengan tuntas, tertib dalam antrian, dan menyelesaikan tugas yang diberikan) setelah diobservasi hasilnya seperti pada tabel 1 . 
Tabel 1. Kondisi Awal Sopan Santun Siswa TKIT Al Furqon Maospati

\begin{tabular}{|c|c|c|c|c|c|c|c|c|c|c|c|c|c|}
\hline \multirow{3}{*}{ No } & \multirow{3}{*}{$\begin{array}{l}\text { Nomor } \\
\text { Induk }\end{array}$} & \multicolumn{12}{|c|}{ Aspek yang diamati } \\
\hline & & \multicolumn{3}{|c|}{$\begin{array}{c}\text { Mengucapkan } \\
\text { terimakasih jika } \\
\text { diberi }\end{array}$} & \multicolumn{3}{|c|}{$\begin{array}{l}\text { Mengucapkan minta } \\
\text { tolong jika perlu } \\
\text { bantuan }\end{array}$} & \multicolumn{3}{|c|}{$\begin{array}{l}\text { Meminta maaf jika } \\
\text { salah }\end{array}$} & \multicolumn{3}{|c|}{$\begin{array}{c}\text { Mengucap } \\
\text { salam dan } \\
\text { mencium } \\
\text { tangan guru }\end{array}$} \\
\hline & & $\star$ & $\star \star$ & $\begin{array}{c}\star \star \\
\star\end{array}$ & $\star$ & $\star \star$ & $\begin{array}{c}\star \star \\
\star\end{array}$ & $\star$ & $\star \star$ & $\begin{array}{c}\star \star \\
\star\end{array}$ & $\star$ & $\star \star$ & $\begin{array}{c}\star \star \\
\star\end{array}$ \\
\hline 1 & 01771 & $\sqrt{ }$ & & & $\sqrt{ }$ & & & $\sqrt{ }$ & & & & $\sqrt{ }$ & \\
\hline 2 & 01777 & & $\sqrt{ }$ & & $\sqrt{ }$ & & & & $\sqrt{ }$ & & & $\sqrt{ }$ & \\
\hline 3 & 01784 & $\sqrt{ }$ & & & $\sqrt{ }$ & & & $\sqrt{ }$ & & & & $\sqrt{ }$ & \\
\hline 4 & 01788 & $\sqrt{ }$ & & & $\sqrt{ }$ & & & $\sqrt{ }$ & & & & $\sqrt{ }$ & \\
\hline 5 & 01017 & $\sqrt{ }$ & & & $\sqrt{ }$ & & & $\sqrt{ }$ & & & & $\sqrt{ }$ & \\
\hline 6 & 01791 & & $\sqrt{ }$ & & & $\sqrt{ }$ & & & $\sqrt{ }$ & & & $\sqrt{ }$ & \\
\hline 7 & 01792 & $\sqrt{ }$ & & & $\sqrt{ }$ & & & $\sqrt{ }$ & & & $\sqrt{ }$ & & \\
\hline 8 & 01803 & & $\sqrt{ }$ & & & $\sqrt{ }$ & & $\sqrt{ }$ & & & & $\sqrt{ }$ & \\
\hline 9 & 01807 & $\sqrt{ }$ & & & $\sqrt{ }$ & & & $\sqrt{ }$ & & & $\sqrt{ }$ & & \\
\hline 10 & 01814 & $\sqrt{ }$ & & & $\sqrt{ }$ & & & $\sqrt{ }$ & & & $\sqrt{ }$ & & \\
\hline 11 & 01816 & $\sqrt{ }$ & & & $\sqrt{ }$ & & & $\sqrt{ }$ & & & $\sqrt{ }$ & & \\
\hline 12 & 01825 & & $\sqrt{ }$ & & & $\sqrt{ }$ & & & $\sqrt{ }$ & & & $\sqrt{ }$ & \\
\hline 13 & 01832 & $\sqrt{ }$ & & & $\sqrt{ }$ & & & $\sqrt{ }$ & & & $\sqrt{ }$ & & \\
\hline 14 & 01842 & & & $\sqrt{ }$ & & $\sqrt{ }$ & & & & $\sqrt{ }$ & & & $\sqrt{ }$ \\
\hline 15 & 01857 & $\sqrt{ }$ & & & $\sqrt{ }$ & & & $\sqrt{ }$ & & & & $\sqrt{ }$ & \\
\hline 16 & 01849 & $\sqrt{ }$ & & & $\sqrt{ }$ & & & & $\sqrt{ }$ & & & $\sqrt{ }$ & \\
\hline 17 & 01811 & $\sqrt{ }$ & & & $\sqrt{ }$ & & & & $\sqrt{ }$ & & & $\sqrt{ }$ & \\
\hline 18 & 01834 & & $\sqrt{ }$ & & & $\sqrt{ }$ & & & $\sqrt{ }$ & & & $\sqrt{ }$ & \\
\hline 19 & 01808 & & & $\sqrt{ }$ & & & $\sqrt{ }$ & & & $\sqrt{ }$ & & $\sqrt{ }$ & \\
\hline 20 & 01785 & & $\sqrt{ }$ & & & $\sqrt{ }$ & & $\sqrt{ }$ & & & & $\sqrt{ }$ & \\
\hline & Jumlah & 12 & 6 & 2 & 13 & 6 & 1 & 12 & 6 & 2 & 5 & 14 & 1 \\
\hline & Persentase & 60 & 30 & 10 & 65 & 30 & 5 & 60 & 30 & 10 & 25 & 70 & 5 \\
\hline
\end{tabular}

Keterangan:

A. Mengucapkan terimakasih jika di beri

$\star \quad$ : Anak belum mau mengucapkan terimakasih

$\star \star \quad$ : Anak mau mengucapkan terimakasih dengan bimbingan guru

$\star \star \star \quad$ : Anak mau mengucapkan terimakasih dengan kesadaran sendiri

B. Mengucapkan minta tolong jika minta bantuan

$\star \quad$ : Anak belum mau mengucapkan kata tolong

$\star \star \quad$ : Anak mau mengucapkan kata tolong dengan bimbingan guru

$\star \star \star \quad$ : Anak mau mengucapkan kata tolong dengan kesadaran sendiri

C. Meminta maaf jika salah

$\star \quad$ : Anak belum mau mengucapkan kata maaf

$\star \star \quad$ : Anak mau mengucapkan kata maaf dengan bimbingan guru

$\star \star \star \quad$ : Anak mau mengucapkan kata maaf dengan kesadaran sendiri

D. Mengucapkan salam dan mencium tangan guru

$\star \quad \quad$ : Anak belum mau mengucapkan salam dan mencium tangan guru

$\star \star \quad$ : Anak mau mengucapkan salam dan mencium tangan guru dengan bimbingan guru

$\star \star \star \quad$ : Anak mau mengucapkan salam dan mencium tangan guru dengan kesadaran sendiri

Dari tabel 1 diketahui bahwa rata-rata persentase ketuntasan masih sangat rendah yakni 7,5\%. \%. Rendahnya tingkat sopan santun di kalangan siswa ini bukan berarti mereka tidak mendapatkan pendidikan sopan santun dalam keluarga dan di sekolah, namun lebih ke arah faktor 
kesadaran dan pembiasaan yang kurang, sehingga peserta didik masih harus diingatkan oleh guru dalam melaksanakan indikator-indikator tersebut.

Tabel 2. Kondisi Awal Nilai Disiplin Siswa TKIT Al Furqon Maospati

\begin{tabular}{|c|c|c|c|c|c|c|c|c|c|c|c|c|c|}
\hline \multirow{3}{*}{ No } & \multirow{3}{*}{$\begin{array}{l}\text { Nomor } \\
\text { Induk }\end{array}$} & \multicolumn{12}{|c|}{ Aspek yang diamati } \\
\hline & & \multicolumn{3}{|c|}{$\begin{array}{l}\text { Merapikan mainan } \\
\text { dan alat tulis }\end{array}$} & \multicolumn{3}{|c|}{$\begin{array}{c}\text { Mengikuti kegiatan } \\
\text { dengan tuntas }\end{array}$} & \multicolumn{3}{|c|}{$\begin{array}{l}\text { Tertib dalam } \\
\text { antrian }\end{array}$} & \multicolumn{3}{|c|}{$\begin{array}{c}\text { Menyelesaikan } \\
\text { tugas yang } \\
\text { diberikan }\end{array}$} \\
\hline & & $\star$ & $\star \star$ & $\begin{array}{c}\star \star \\
\star\end{array}$ & $\star$ & $\star \star$ & $\begin{array}{c}\star \star \\
\star\end{array}$ & $\star$ & $\star \star$ & $\begin{array}{c}\star \star \\
\star\end{array}$ & $\star$ & $\star \star$ & $\begin{array}{c}\star \star \\
\star\end{array}$ \\
\hline 1 & 01771 & $\sqrt{ }$ & & & $\sqrt{ }$ & & & $\sqrt{ }$ & & & $\sqrt{ }$ & & \\
\hline 2 & 01777 & & $\sqrt{ }$ & & & & $\sqrt{ }$ & & & $\sqrt{ }$ & & $\sqrt{ }$ & \\
\hline 3 & 01784 & $\sqrt{ }$ & & & $\sqrt{ }$ & & & $\sqrt{ }$ & & & $\sqrt{ }$ & & \\
\hline 4 & 01788 & & $\sqrt{ }$ & & & & $\sqrt{ }$ & & & $\sqrt{ }$ & $\sqrt{ }$ & & \\
\hline 5 & 01017 & $\sqrt{ }$ & & & $\sqrt{ }$ & & & $\sqrt{ }$ & & & & $\sqrt{ }$ & \\
\hline 6 & 01791 & $\sqrt{ }$ & & & & $\sqrt{ }$ & & & $\sqrt{ }$ & & & & $\sqrt{ }$ \\
\hline 7 & 01792 & $\sqrt{ }$ & & & $\sqrt{ }$ & & & $\sqrt{ }$ & & & & $\sqrt{ }$ & \\
\hline 8 & 01803 & & $\sqrt{ }$ & & & $\sqrt{ }$ & & & $\sqrt{ }$ & & & $\sqrt{ }$ & \\
\hline 9 & 01807 & $\sqrt{ }$ & & & $\sqrt{ }$ & & & $\sqrt{ }$ & & & $\sqrt{ }$ & & \\
\hline 10 & 01814 & $\sqrt{ }$ & & & $\sqrt{ }$ & & & $\sqrt{ }$ & & & $\sqrt{ }$ & & \\
\hline 11 & 01816 & $\sqrt{ }$ & & & & $\sqrt{ }$ & & & $\sqrt{ }$ & & & & $\sqrt{ }$ \\
\hline 12 & 01825 & & $\sqrt{ }$ & & & $\sqrt{ }$ & & & $\sqrt{ }$ & & & $\sqrt{ }$ & \\
\hline 13 & 01832 & $\sqrt{ }$ & & & & $\sqrt{ }$ & & & $\sqrt{ }$ & & $\sqrt{ }$ & & \\
\hline 14 & 01842 & & & $\sqrt{ }$ & & & $\sqrt{ }$ & $\sqrt{ }$ & & & & & $\sqrt{ }$ \\
\hline 15 & 01857 & & & $\sqrt{ }$ & $\sqrt{ }$ & & & $\sqrt{ }$ & & & & & $\sqrt{ }$ \\
\hline 16 & 01849 & & $\sqrt{ }$ & & & $\sqrt{ }$ & & & $\sqrt{ }$ & & & $\sqrt{ }$ & \\
\hline 17 & 01811 & & $\sqrt{ }$ & & $\sqrt{ }$ & & & $\sqrt{ }$ & & & & $\sqrt{ }$ & \\
\hline 18 & 01834 & & $\sqrt{ }$ & & & & & & $\sqrt{ }$ & & & $\sqrt{ }$ & \\
\hline 19 & 01808 & & $\sqrt{ }$ & & & $\sqrt{ }$ & & $\sqrt{ }$ & & & & $\sqrt{ }$ & \\
\hline 20 & 01785 & & $\sqrt{ }$ & & $\sqrt{ }$ & $\sqrt{ }$ & & $\sqrt{ }$ & & & $\sqrt{ }$ & & \\
\hline & Jumlah & 9 & 9 & 2 & 9 & 8 & 3 & 11 & 7 & 2 & 7 & 9 & 4 \\
\hline & Persentase & 45 & 45 & 10 & 45 & 40 & 15 & 55 & 35 & 10 & 35 & 45 & 20 \\
\hline
\end{tabular}

Keterangan:

A. Merapikan mainan dan alat tulis

$\star \quad$ : Anak belum mau merapikan mainan dan alat tulis

$\star \star \quad$ : Anak mau merapikan mainan dan alat tulis dengan bimbingan guru

$\star \star \star \quad$ : Anak mau merapikan mainan dan alat tulis kesadaran sendiri

B. Mengikuti kegiatan dengan tuntas

$\star \quad$ : Anak belum mau mengikuti kegiatan dengan tuntas

$\star \star \quad$ : Anak mau mengikuti kegiatan dengan tuntas dengan bimbingan guru

$\star \star \star \quad$ : Anak mau mengikuti kegiatan dengan tuntas dengan kesadaran sendiri

C. Tertib dalam antrian

$\star \quad$ : Anak belum mau tertib dalam antrian

$\star \star \quad:$ Anak mau tertib dalam antrian dengan bimbingan guru

$\star \star \star \quad$ : Anak mau tertib dalam antrian dengan kesadaran sendiri

D. Menyelesaikan tugas yang diberikan

$\star \quad$ : Anak belum mau menyelesaikan tugas yang diberikan oleh guru

$\star \star \quad$ : Anak mau menyelesaiakn tugas yang diberikan dengan bimbingan guru

$\star \star \star \quad$ : Anak mau menyelesaiakn tugas yang diberikan dengan kesadaran sendiri

Dari tabel 2 diketahui bahwa rata-rata persentase disiplin siswa berkisar pada 13,75\%.

Hal ini yang menjadi dasar bagi peneliti untuk melaksanakan tindakan pada siklus berikutnya. 


\subsection{Siklus 1}

Dalam merancang pembelajaran siklus I, peneliti bekerjasama dengan guru kelas sebagai praktikan untuk menerapkan tembang dolanan sebagai media pesan karakter sopan santun dan disiplin. Setelah Rencana Pelaksanaan Pembelajaran Harian (RPPH) disusun, maka siklus I dilaksanakan dan sebagai observernya peneliti. Hasil pengamatan terhadap sopan santun dan disiplin siswa kelas B3 sebagaimana tercantum dalam tabel 3 dan 4 .

Tabel 3. Nilai Sopan Santun Siswa TKIT Al Furqon Maospati pada Siklus 1

\begin{tabular}{|c|c|c|c|c|c|c|c|c|c|c|c|c|c|}
\hline \multirow{3}{*}{ No } & \multirow{3}{*}{$\begin{array}{l}\text { Nomor } \\
\text { Induk }\end{array}$} & \multicolumn{12}{|c|}{ Aspek yang diamati } \\
\hline & & \multicolumn{3}{|c|}{$\begin{array}{c}\text { Mengucapkan } \\
\text { terimakasih jika } \\
\text { diberi }\end{array}$} & \multicolumn{3}{|c|}{$\begin{array}{c}\text { Mengucapkan minta } \\
\text { tolong jika perlu } \\
\text { bantuan }\end{array}$} & \multicolumn{3}{|c|}{$\begin{array}{c}\text { Meminta maaf jika } \\
\text { salah }\end{array}$} & \multicolumn{3}{|c|}{$\begin{array}{l}\text { Mengucap } \\
\text { salam dan } \\
\text { mencium } \\
\text { tangan guru }\end{array}$} \\
\hline & & $\star$ & $\star \star$ & $\begin{array}{c}\star \star \\
\star\end{array}$ & $\star$ & $\star \star$ & $\begin{array}{c}\star \star \\
\star\end{array}$ & $\star$ & $\star \star$ & $\begin{array}{c}\star \star \\
\star\end{array}$ & $\star$ & $\star \star$ & $\begin{array}{c}\star \star \\
\star\end{array}$ \\
\hline 1 & 01771 & $\sqrt{ }$ & & & $\sqrt{ }$ & & & $\sqrt{ }$ & & & & $\sqrt{ }$ & \\
\hline 2 & 01777 & & & $\sqrt{ }$ & & $\sqrt{ }$ & & & & $\sqrt{ }$ & & & $\sqrt{ }$ \\
\hline 3 & 01784 & & $\sqrt{ }$ & & & $\sqrt{ }$ & & & $\sqrt{ }$ & & & & $\sqrt{ }$ \\
\hline 4 & 01788 & & $\sqrt{ }$ & & $\sqrt{ }$ & & & & $\sqrt{ }$ & & & $\sqrt{ }$ & \\
\hline 5 & 01017 & $\sqrt{ }$ & & & $\sqrt{ }$ & & & $\sqrt{ }$ & & & & & $\sqrt{ }$ \\
\hline 6 & 01791 & & $\sqrt{ }$ & & & & $\sqrt{ }$ & & & $\sqrt{ }$ & & & $\sqrt{ }$ \\
\hline 7 & 01792 & & $\sqrt{ }$ & & & $\sqrt{ }$ & & $\sqrt{ }$ & & & & $\sqrt{ }$ & \\
\hline 8 & 01803 & & & $\sqrt{ }$ & & $\sqrt{ }$ & & & $\sqrt{ }$ & & & $\sqrt{ }$ & \\
\hline 9 & 01807 & & $\sqrt{ }$ & & & & $\sqrt{ }$ & & $\sqrt{ }$ & & $\sqrt{ }$ & & \\
\hline 10 & 01814 & $\sqrt{ }$ & & & $\sqrt{ }$ & & & $\sqrt{ }$ & & & & $\sqrt{ }$ & \\
\hline 11 & 01816 & $\sqrt{ }$ & & & $\sqrt{ }$ & & & & $\sqrt{ }$ & & & $\sqrt{ }$ & \\
\hline 12 & 01825 & & $\sqrt{ }$ & & & $\sqrt{ }$ & & & & $\sqrt{ }$ & & $\sqrt{ }$ & \\
\hline 13 & 01832 & $\sqrt{ }$ & & & $\sqrt{ }$ & & & $\sqrt{ }$ & & & $\sqrt{ }$ & & \\
\hline 14 & 01842 & & & $\sqrt{ }$ & & $\sqrt{ }$ & & & & $\sqrt{ }$ & & & $\sqrt{ }$ \\
\hline 15 & 01857 & $\sqrt{ }$ & & & & $\sqrt{ }$ & & $\sqrt{ }$ & & & & $\sqrt{ }$ & \\
\hline 16 & 01849 & & & $\sqrt{ }$ & & $\sqrt{ }$ & & & $\sqrt{ }$ & & & & $\sqrt{ }$ \\
\hline 17 & 01811 & & $\sqrt{ }$ & & $\sqrt{ }$ & & & & $\sqrt{ }$ & & & $\sqrt{ }$ & \\
\hline 18 & 01834 & & & $\sqrt{ }$ & & & $\sqrt{ }$ & & & $\sqrt{ }$ & & & $\sqrt{ }$ \\
\hline 19 & 01808 & & & $\sqrt{ }$ & & & $\sqrt{ }$ & & & $\sqrt{ }$ & & & $\sqrt{ }$ \\
\hline 20 & 01785 & & $\sqrt{ }$ & & & $\sqrt{ }$ & & $\sqrt{ }$ & & & & $\sqrt{ }$ & \\
\hline & Jumlah & 6 & 8 & 6 & 7 & 8 & 4 & 7 & 7 & 6 & 2 & 10 & 8 \\
\hline & Persentase & 30 & 40 & 30 & 35 & 40 & 20 & 35 & 35 & 30 & 10 & 50 & 40 \\
\hline
\end{tabular}


Tabel 4. Nilai Disiplin Siswa TKIT Al Furqon Maospati pada Siklus 1

\begin{tabular}{|c|c|c|c|c|c|c|c|c|c|c|c|c|c|}
\hline \multirow{3}{*}{ No } & \multirow{3}{*}{$\begin{array}{l}\text { Nomor } \\
\text { Induk }\end{array}$} & \multicolumn{12}{|c|}{ Aspek yang diamati } \\
\hline & & \multicolumn{3}{|c|}{$\begin{array}{c}\text { Merapikan mainan } \\
\text { dan alat tulis }\end{array}$} & \multicolumn{3}{|c|}{$\begin{array}{c}\text { Mengikuti kegiatan } \\
\text { dengan tuntas }\end{array}$} & \multicolumn{3}{|c|}{$\begin{array}{l}\text { Tertib dalam } \\
\text { antrian }\end{array}$} & \multicolumn{3}{|c|}{$\begin{array}{l}\text { Menyelesaikan } \\
\text { tugas yang } \\
\text { diberikan }\end{array}$} \\
\hline & & $\star$ & $\star \star$ & $\begin{array}{c}\star \star \\
\star\end{array}$ & $\star$ & $\star \star$ & $\begin{array}{l}\star \star \\
\star\end{array}$ & $\star$ & $\begin{array}{l}\star \\
\star\end{array}$ & $\begin{array}{l}\star \star \\
\star\end{array}$ & $\star$ & $\star \star$ & $\begin{array}{l}\star \star \\
\star\end{array}$ \\
\hline 1 & 01771 & $\sqrt{ }$ & & & $\sqrt{ }$ & & & $\sqrt{ }$ & & & $\sqrt{ }$ & & \\
\hline 2 & 01777 & & $\sqrt{ }$ & & & & $\sqrt{ }$ & & & $\sqrt{ }$ & & & $\sqrt{ }$ \\
\hline 3 & 01784 & $\sqrt{ }$ & $\sqrt{ }$ & & & $\sqrt{ }$ & & & $\sqrt{ }$ & & & $\sqrt{ }$ & \\
\hline 4 & $\begin{array}{l}01788 \\
\end{array}$ & & & $\sqrt{ }$ & & & $\sqrt{ }$ & & & $\sqrt{ }$ & & $\sqrt{ }$ & \\
\hline 5 & 01017 & $\sqrt{ }$ & $\sqrt{ }$ & & $\sqrt{ }$ & & & $\sqrt{ }$ & & & & & $\sqrt{ }$ \\
\hline 6 & 01791 & & $\sqrt{ }$ & & & $\sqrt{ }$ & & & $\sqrt{ }$ & & & & $\sqrt{ }$ \\
\hline 7 & 01792 & $\sqrt{ }$ & & & $\sqrt{ }$ & & & $\sqrt{ }$ & & & & $\sqrt{ }$ & \\
\hline 8 & 01803 & & $\sqrt{ }$ & & & $\sqrt{ }$ & & & $\sqrt{ }$ & & & & $\sqrt{ }$ \\
\hline 9 & 01807 & & & $\sqrt{ }$ & & $\sqrt{ }$ & & & $\sqrt{ }$ & & $\sqrt{ }$ & & \\
\hline 10 & 01814 & & $\sqrt{ }$ & & $\sqrt{ }$ & & & & $\sqrt{ }$ & & $\sqrt{ }$ & & \\
\hline 11 & 01816 & $\sqrt{ }$ & & & & $\sqrt{ }$ & & & & $\sqrt{ }$ & & & $\sqrt{ }$ \\
\hline 12 & 01825 & & & $\sqrt{ }$ & & & $\sqrt{ }$ & & & $\sqrt{ }$ & & $\sqrt{ }$ & \\
\hline 13 & 01832 & $\sqrt{ }$ & & & & & $\sqrt{ }$ & & $\sqrt{ }$ & & $\sqrt{ }$ & & \\
\hline 14 & 01842 & & & $\sqrt{ }$ & & & $\sqrt{ }$ & $\sqrt{ }$ & & & & & $\sqrt{ }$ \\
\hline 15 & 01857 & & & $\sqrt{ }$ & & $\sqrt{ }$ & & & $\sqrt{ }$ & & & & $\sqrt{ }$ \\
\hline 16 & 01849 & & $\sqrt{ }$ & & & $\sqrt{ }$ & & & $\sqrt{ }$ & & & & $\sqrt{ }$ \\
\hline 17 & 01811 & & $\sqrt{ }$ & & $\sqrt{ }$ & & & $\sqrt{ }$ & & & & $\sqrt{ }$ & \\
\hline 18 & 01834 & & & $\sqrt{ }$ & & & $\sqrt{ }$ & & & $\sqrt{ }$ & & & $\sqrt{ }$ \\
\hline 19 & 01808 & & & $\sqrt{ }$ & & & $\sqrt{ }$ & $\sqrt{ }$ & & & & & $\sqrt{ }$ \\
\hline 20 & 01785 & & $\sqrt{ }$ & & $\sqrt{ }$ & & & $\sqrt{ }$ & & & & $\sqrt{ }$ & \\
\hline & Jumlah & 6 & 9 & 7 & 6 & 7 & 7 & 7 & 8 & 5 & 4 & 6 & 10 \\
\hline & ersentase & 30 & 45 & 35 & 30 & 35 & 35 & 35 & 40 & 25 & 20 & 30 & 50 \\
\hline
\end{tabular}

Berdasar tabel 3 dan 4 tersebut di atas diketahui bahwa sopan santun siswa B3 mengalami peningkatan dibanding dengan kondisi prasiklus. Peningkatannya sebesar 30\% untuk sopan santun dan 36\% untuk disiplin. Selain itu, hasil pengamatan menunjukkan; (1). Siswa kurang perhatian saat dijelaskan tentang sopan santun; (2) Siswa kurang antusias dan cenderung ramai pada saat pembelajaran; (3) Siswa menganggap aneh/asing terhadap bahasa jawa; dan (4) Guru kurang bisa menguasai kelas.

Hasil refleksi tersebut membuat peneliti dan guru kelas merencanakan perbaikan untuk siklus 2 yang meliputi; (1) Mengoptimalkan peran guru dalam pembelajaran agar sesuai dengan yang diharapkan yaitu meningkatkan karakter kearah yang lebih baik terutama sopan santun dan disiplin; (2) Menggunakan bahasa dan ekspresi yang lebih menarik bagi peserta didik; dan (3) Pembentukan kelompok-kelompok kecil agar guru lebih mudah dalam penguasaan kelas

\subsection{Siklus 2}

Mengacu pada rencana perbaikan pada hasil refleksi siklus I, maka peneliti bersama guru kelas merancang Rencana Pelaksanaan Pembelajaran Harian (RPPH) siklus 2. Peneliti tetap sebagai observer dan hasilnya sebagaimana tercantum dalam, tabel 5 dan 6 . Berdasar tabel 5 dan 6 di atas diketahui bahwa sopan santun dan disiplin siswa kelas B3 mengalami peningkatan 
dibandingkan dengan hasil siklus 1 . Rata-rata presentase sopan santun siswa menjadi $87,5 \%$ dan rata-rata presentase disiplin menjadi $86,75 \%$. Hasil tersebut menandakan bahwa tingkat ketuntasan $80 \%$ yang dijadikan patokan telah tercapai sehingga siklus dihentikan atau tidak perlu dilanjutkan ke siklus berikutnya.

Tabel 5. Nilai Sopan Santun Siswa TKIT Al Furqon Maospati pada Siklus 2

\begin{tabular}{|c|c|c|c|c|c|c|c|c|c|c|c|c|c|}
\hline \multirow{3}{*}{ No } & \multirow{3}{*}{$\begin{array}{l}\text { Nomor } \\
\text { Induk }\end{array}$} & \multicolumn{12}{|c|}{ Aspek yang diamati } \\
\hline & & \multicolumn{3}{|c|}{$\begin{array}{c}\text { Mengucapkan } \\
\text { terimakasih jika } \\
\text { diberi }\end{array}$} & \multicolumn{3}{|c|}{$\begin{array}{c}\text { Mengucapkan } \\
\text { minta tolong jika } \\
\text { perlu bantuan }\end{array}$} & \multicolumn{3}{|c|}{$\begin{array}{l}\text { Meminta maaf } \\
\text { jika salah }\end{array}$} & \multicolumn{3}{|c|}{$\begin{array}{l}\text { Mengucap } \\
\text { salam dan } \\
\text { mencium } \\
\text { tangan guru }\end{array}$} \\
\hline & & $\star$ & $\star \star$ & $\begin{array}{c}\star \star \\
\star \\
\end{array}$ & $\star$ & $\star \star$ & $\begin{array}{c}\star \star \\
\star\end{array}$ & $\star$ & $\begin{array}{l}\star \\
\star \\
\end{array}$ & $\begin{array}{l}\star \star \\
\star \\
\end{array}$ & $\star$ & $\star \star$ & $\begin{array}{c}\star \star \\
\star \\
\end{array}$ \\
\hline 1 & 01771 & & $\sqrt{ }$ & & & $\sqrt{ }$ & & & $\sqrt{ }$ & & & & $\sqrt{ }$ \\
\hline 2 & 01777 & & & $\sqrt{ }$ & & & $\sqrt{ }$ & & & $\sqrt{ }$ & & & $\sqrt{ }$ \\
\hline 3 & 01784 & & & $\sqrt{ }$ & & & $\sqrt{ }$ & & & $\sqrt{ }$ & & & $\sqrt{ }$ \\
\hline 4 & 01788 & & & $\sqrt{ }$ & & & $\sqrt{ }$ & & & $\sqrt{ }$ & & & $\sqrt{ }$ \\
\hline 5 & 01017 & $\sqrt{ }$ & & & & & $\sqrt{ }$ & & $\sqrt{ }$ & & & & $\sqrt{ }$ \\
\hline 6 & 01791 & & & $\sqrt{ }$ & & & $\sqrt{ }$ & & & $\sqrt{ }$ & & & $\sqrt{ }$ \\
\hline 7 & 01792 & & & $\sqrt{ }$ & & $\sqrt{ }$ & & & & $\sqrt{ }$ & & & $\sqrt{ }$ \\
\hline 8 & 01803 & & & $\sqrt{ }$ & & & $\sqrt{ }$ & & & $\sqrt{ }$ & & & $\sqrt{ }$ \\
\hline 9 & 01807 & & & $\sqrt{ }$ & & & $\sqrt{ }$ & & & $\sqrt{ }$ & & & $\sqrt{ }$ \\
\hline 10 & 01814 & & & $\sqrt{ }$ & & & $\sqrt{ }$ & & & $\sqrt{ }$ & & & $\sqrt{ }$ \\
\hline 11 & 01816 & & $\sqrt{ }$ & & & & $\sqrt{ }$ & & & $\sqrt{ }$ & & & $\sqrt{ }$ \\
\hline 12 & 01825 & & & $\sqrt{ }$ & & & $\sqrt{ }$ & & & $\sqrt{ }$ & & & $\sqrt{ }$ \\
\hline 13 & 01832 & & $\sqrt{ }$ & & & & $\sqrt{ }$ & & & $\sqrt{ }$ & & $\sqrt{ }$ & \\
\hline 14 & 01842 & & & $\sqrt{ }$ & & & $\sqrt{ }$ & & & $\sqrt{ }$ & & & $\sqrt{ }$ \\
\hline 15 & 01857 & & & $\sqrt{ }$ & & & $\sqrt{ }$ & & & $\sqrt{ }$ & & & $\sqrt{ }$ \\
\hline 16 & 01849 & & & $\sqrt{ }$ & & & $\sqrt{ }$ & & & $\sqrt{ }$ & & & $\sqrt{ }$ \\
\hline 17 & 01811 & & & $\sqrt{ }$ & $\sqrt{ }$ & & & & & $\sqrt{ }$ & & & $\sqrt{ }$ \\
\hline 18 & 01834 & & & $\sqrt{ }$ & & & $\sqrt{ }$ & & & $\sqrt{ }$ & & & $\sqrt{ }$ \\
\hline 19 & 01808 & & & $\sqrt{ }$ & & & $\sqrt{ }$ & & & $\sqrt{ }$ & & & $\sqrt{ }$ \\
\hline 20 & 01785 & & & $\sqrt{ }$ & & & $\sqrt{ }$ & & & $\sqrt{ }$ & & & $\sqrt{ }$ \\
\hline & Jumlah & 1 & 3 & 16 & 1 & 2 & 17 & 0 & 2 & 18 & 0 & 1 & 19 \\
\hline & Persentase & 5 & 15 & 80 & 5 & 20 & 85 & 0 & 10 & 90 & 0 & 5 & 95 \\
\hline
\end{tabular}


Tabel 6. Nilai Disiplin Siswa TKIT Al Furqon Maospati pada Siklus 2

\begin{tabular}{|c|c|c|c|c|c|c|c|c|c|c|c|c|c|}
\hline \multirow{3}{*}{ No } & \multirow{3}{*}{$\begin{array}{l}\text { Nomor } \\
\text { Induk }\end{array}$} & \multicolumn{12}{|c|}{ Aspek yang diamati } \\
\hline & & \multicolumn{3}{|c|}{$\begin{array}{l}\text { Merapikan mainan } \\
\text { dan alat tulis }\end{array}$} & \multicolumn{3}{|c|}{$\begin{array}{l}\text { Mengikuti kegiatan } \\
\text { dengan tuntas }\end{array}$} & \multicolumn{3}{|c|}{$\begin{array}{l}\text { Tertib dalam } \\
\text { antrian }\end{array}$} & \multicolumn{3}{|c|}{$\begin{array}{l}\text { Menyelesaikan } \\
\text { tugas yang } \\
\text { diberikan }\end{array}$} \\
\hline & & $\star$ & $\star \star$ & $\begin{array}{l}\star \star \\
\star\end{array}$ & $\star$ & $\star \star$ & $\begin{array}{c}\star \star \\
\star\end{array}$ & $\star$ & $\begin{array}{l}\star \\
\star\end{array}$ & $\begin{array}{l}\star \star \\
\star\end{array}$ & $\star$ & $\star \star$ & $\begin{array}{l}\star \star \\
\star\end{array}$ \\
\hline 1 & 01771 & & & $\sqrt{ }$ & & & $\sqrt{ }$ & $\sqrt{ }$ & & & & $\sqrt{ }$ & \\
\hline 2 & 01777 & & & $\sqrt{ }$ & & & $\sqrt{ }$ & & & $\sqrt{ }$ & & & $\sqrt{ }$ \\
\hline 3 & 01784 & & & $\sqrt{ }$ & & & $\sqrt{ }$ & & $\sqrt{ }$ & & & & $\sqrt{ }$ \\
\hline 4 & 01788 & & & $\sqrt{ }$ & & & $\sqrt{ }$ & & & $\sqrt{ }$ & & & $\sqrt{ }$ \\
\hline 5 & 01017 & & & $\sqrt{ }$ & & $\sqrt{ }$ & & & & $\sqrt{ }$ & & & $\sqrt{ }$ \\
\hline 6 & 01791 & & $\sqrt{ }$ & & & & $\sqrt{ }$ & & & $\sqrt{ }$ & & & $\sqrt{ }$ \\
\hline 7 & 01792 & $\sqrt{ }$ & & & & & $\sqrt{ }$ & & & $\sqrt{ }$ & & & $\sqrt{ }$ \\
\hline 8 & 01803 & & & $\sqrt{ }$ & & & $\sqrt{ }$ & & & $\sqrt{ }$ & & & $\sqrt{ }$ \\
\hline 9 & 01807 & & & $\sqrt{ }$ & & & $\sqrt{ }$ & & & $\sqrt{ }$ & & & $\sqrt{ }$ \\
\hline 10 & 01814 & & $\sqrt{ }$ & & & $\sqrt{ }$ & & & & $\sqrt{ }$ & & & $\sqrt{ }$ \\
\hline 11 & 01816 & & & $\sqrt{ }$ & & & $\sqrt{ }$ & & & $\sqrt{ }$ & & & $\sqrt{ }$ \\
\hline 12 & 01825 & & & $\sqrt{ }$ & & & $\sqrt{ }$ & & & $\sqrt{ }$ & & & $\sqrt{ }$ \\
\hline 13 & 01832 & & $\sqrt{ }$ & & & & $\sqrt{ }$ & & & $\sqrt{ }$ & & & $\sqrt{ }$ \\
\hline 14 & 01842 & & & $\sqrt{ }$ & & & $\sqrt{ }$ & & $\sqrt{ }$ & & & & $\sqrt{ }$ \\
\hline 15 & 01857 & & & $\sqrt{ }$ & & & $\sqrt{ }$ & & & $\sqrt{ }$ & & & $\sqrt{ }$ \\
\hline 16 & 01849 & & & $\sqrt{ }$ & & & $\sqrt{ }$ & & & $\sqrt{ }$ & & & $\sqrt{ }$ \\
\hline 17 & 01811 & & & $\sqrt{ }$ & & & $\sqrt{ }$ & $\sqrt{ }$ & & & & & $\sqrt{ }$ \\
\hline 18 & 01834 & & & $\sqrt{ }$ & & & $\sqrt{ }$ & & & $\sqrt{ }$ & & & $\sqrt{ }$ \\
\hline 19 & 01808 & & & $\sqrt{ }$ & & & $\sqrt{ }$ & & & $\sqrt{ }$ & & & $\sqrt{ }$ \\
\hline 20 & 01785 & & $\sqrt{ }$ & & & & $\sqrt{ }$ & & & $\sqrt{ }$ & & & $\sqrt{ }$ \\
\hline & Jumlah & 1 & 3 & 16 & 0 & 2 & 18 & 2 & 2 & 16 & 0 & 1 & 19 \\
\hline & ersentase & 5 & 15 & 80 & 0 & 10 & 90 & 10 & 10 & 80 & 0 & 10 & 95 \\
\hline
\end{tabular}

\section{Pembahasan}

Secara keseluruhan sopan santun dan kedisiplinan siswa mengalami peningkatan. Hal tersebut tercantum dalam rekapitulasi data peningkatan di bawah ini

Tabel 7. Rekapitulasi Data Peningkatan Sopan Santun dan Disiplin

\begin{tabular}{|c|c|c|c|c|c|c|c|c|c|c|}
\hline \multirow{2}{*}{ Siklus } & \multicolumn{5}{|c|}{ Sopan Santun } & \multicolumn{5}{|c|}{ Disiplin } \\
\hline & A & B & $\mathrm{C}$ & $\mathrm{D}$ & Rerata & A & B & $\mathrm{C}$ & $\mathrm{D}$ & Rerata \\
\hline Prasiklus & $10 \%$ & $5 \%$ & $10 \%$ & $5 \%$ & $7,5 \%$ & $10 \%$ & $15 \%$ & $10 \%$ & $20 \%$ & $13,75 \%$ \\
\hline Siklus I & $30 \%$ & $20 \%$ & $30 \%$ & $40 \%$ & $30 \%$ & $35 \%$ & $35 \%$ & $25 \%$ & $50 \%$ & $36,25 \%$ \\
\hline Siklus II & $80 \%$ & $85 \%$ & $90 \%$ & $95 \%$ & $87,5 \%$ & $80 \%$ & $90 \%$ & $80 \%$ & $95 \%$ & $86,25 \%$ \\
\hline
\end{tabular}




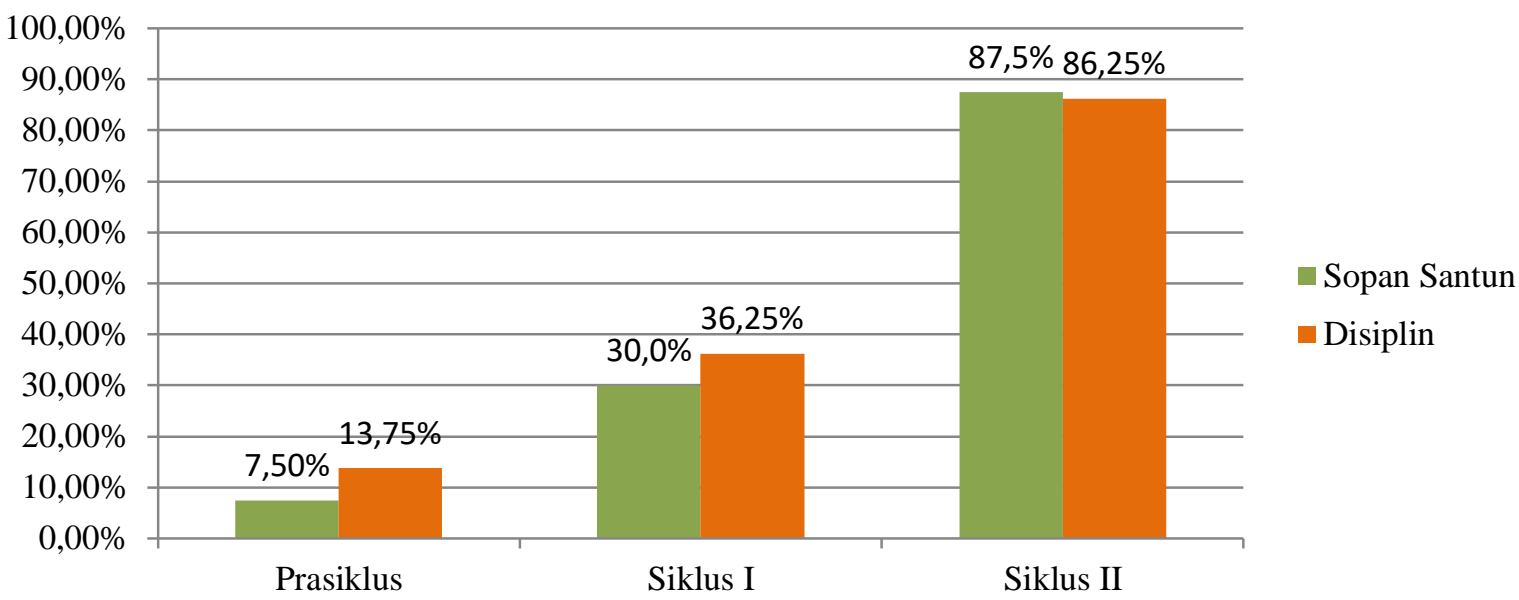

Gambar 2. Nilai Ketuntasan Prasiklus, Siklus I, dan Siklus II

Dari tabel 7 dan gambar 2 dapat diketahui bahwa peningkatan sopan santun dan disiplin siswa B3 TKIT Al Furqon Maospati sangat signifikan. Hal ini menunjukkan bahwa penggunaan tembang dolanan sangat efektif sebagai media pembelajaran untuk meningkatkan karakter terutama sopan santun dan disiplin. Hasil penelitian ini seperti yang diduga sebelumnya dan sejalan artikelnya Veronika, Setiawan, Wardani (2017) bahwa tembang dolanan dapat meningkatkan karakter. Jatirahayu dan Pringgawidagda (2002) yang menyatakan bahwa pembiasaan sopan santun dan disiplin akan efektif bila tidak dibicarakan secara langsung, tetapi disamarkan dengan lagu (laras) dalam hal ini tembang dolanan.

Dengan demikian tembang dolanan selain membuat senang anak-anak juga dapat dijadikan sarana meningkatkan karakter walaupun secara perlahan-lahan nasihat itu akan diserap secara sendirinya. Nilai-nilai itu dapat meresap ke dalam jiwa anak, pemahaman pada makna kata yang terdapat pada tembang dolanan mutlak diperlukan.

\section{Simpulan}

Berdasarkan hasil penelitian dan pembahasan di atas maka dapat disimpulkan bahwa penggunaan tembang dolanan dalam pembelajaran dapat meningkatkan sopan santun dan disiplinan siswa TKIT Al Furqon Maospati Kabupaten Magetan. Peningkatan sopan santun tersebut ditunjukkan dengan nilai persentase klasikal 7,5\% pada prasiklus; $30 \%$ pada siklus 1; dan $87,5 \%$ pada siklus 2 . Sedangkan peningkatan disiplin ditunjukkan dengan nilai presentase klasikal $13,75 \%$ pada prasiklus; $36,25 \%$ pada siklus 1 ; dan $86,25 \%$ pada siklus 2 .

\section{Daftar Pustaka}

Bejo, S. (2005). Manajemen Tenaga Kerja Indonesia Pendekatan Administrarif dan Operasional. Bumi Aksara.

Chazawi, A. (2007). Tindak Pidana Kesopanan. Rajawali Press.

Dessler, G. (2003). Manajemen Sumber Daya Manusia. PT Indeks.

Hadianti, L. S. (2008). Pengaruh Pelaksanaan Tata Terbib Sekolat terhadap Kedisiplinan Belajar Siswa (Penelitian Deskriftif Analisis di SDN Sukakarya II Kecamatan samarang Kabupaten Garut). Jurnal Pendidikan Universitas Garut, 2(1), 1-8.

Hanif, M. (2016). Kesenian Dongkrek (Studi Nilai Budaya Dan Potensinya Sebagai Sumber Pendidikan Karakter). Gulawentah:Jurnal Studi Sosial, 1(2), 132-141.

Jatirahayu, W., dan Pringgawidagda, S. (2002). Puspa Sumekar Budi Pekerti ing Lagu Dolanan 
Anak. CV. Grafika Indah.

Khodiri, A. W. (2019). Nilai Budi Pekerti Dalam Tembang Dolanan Jawa. Universitas Nusantara PGRI Kediri.

Kusnadi. (1999). Diktat Kuliah Pengantar Apresiasi Tembang Jawa. Program Pendidikan Seni Tari. FBS. UNY.

Mustari, M. (2014). Nilai Karakter Refleksi untuk Pendidikan. PT RajaGrafindo Persada.

Parji Parji. (2002). Strategi Pembelajaran Pendidikan Moral pada Era Teknologi Informasi. Jurnal Ilmu Pendidikan, 9(2), 97-107.

Sanjaya, W. (2009). Penelitian Tindakan Kelas. Kencana Prenada Media Group.

Suwardi, E. (2009). Tuntunan Tembang Jawa. Lumbung Ilmu.

Undang-Undang Republik Indonesia Nomor 20 Tahun 2003 Tentang Sistem Pendidikan Nasional.

Veronika, P. Setiawan, B. Wardani, N. (2017). Implementasi Pembelajaran Bahasa Jawa (Materi Tembang Dolanan) Berbasis Pendidikan Karakter Religius dalam Kurikulum 2013. El Harakah JURNAL BUDAYA ISLAM, 19(1), 53-77.

Wulandari, L. D. (2017). Pengaruh Kedisiplinan Terhadap Prestasi Belajar Siswa Mata Pelajaran Ekonomi Kelas XI pada SMA Negeri 4 Depok. JUDIKA (JURNAL PENDIDIKAN UNSIKA), 5(2), 148-151.

Zuriah, N. (2007). Pendidikan Moral dan Budi Pekerti dalam Perspektif Perubahan Mengagas platform Pendidikan Budi Pekerti secara Kontekstual dan Futuristik. PT Bumi Aksara. 